Evans, M.R., J.E. Barrett, B.K. Harbaugh, and G.A. Clark. 1992. No-runoff watering systems for foliage and flowering potted plant production. Fla. Coop. Ext. Serv. Circ. 1059.

Fonteno, W.C. 1996. Growing media: Types and physical/chemical properties, p. 93-122. In: D.W. Reed (ed.). A growers guide to water, media, and nutrition of greenhouse crops. Ball Publishing, Batavia, Ill.

Griffith, Jr., L.P. 1998. Tropical foliage plants-A grower's guide. Ball Publishing, Batavia, Ill.

Guttormsen, G. 1969. Accumulation of salts in sub-irrigation of pot plants. Plant and Soil 31(3):425-438.

Klock-Moore, K.A. and T.K. Broschat. 1999. Differences in bedding plant growth and nitrate loss with a controlled-release fertilizer and two irrigation systems. HortTechnology 9(2):206-209.

Lieth, J.H. 1996. Irrigation systems, p. 129. In: D.W. Reed (ed.). A growers guide to water, media, and nutrition of greenhouse crops. Ball Publishing, Batavia, Ill.

Newman, S.E. 1999. A dry/wet discourse on ebb and flood. Greenhouse Product News 9(8):52-66.

Niedziela, Jr., C.E. and P.V. Nelson. 1992. A rapid method for determining physical properties of undisturbed substrate. HortScience 27:1279-1280.

Poole, R.T. and C.A. Conover. 1992. Fertilizer levels and medium affect foliage plant growth in an ebb and flow irrigation system. J. Environ. Hort. 10(2):81-86.

Warncke, D.D. and D.M. Krauskopf. 1983. Greenhouse growth media: Testing \& nutrition guidelines. Mich. State Univ. Agr. Facts Ext. Bul. E-1736.

Warncke, D.D. 1986. Analyzing greenhouse growth media by saturation extraction method. HortScience 21:223-225.

Yelanich, M.Y. and J.A. Biernbaum. 1993. Root-medium nutrient concentration and growth of poinsettia at three fertilizer concentrations and four leaching fractions. J. Amer. Soc. Hort. Sci. 118(6):771-776.

\section{Susceptibility of Lantana Cultivars to Orthezia insignis}

\author{
Timothy K. Broschat and \\ Thomas J. Weissling ${ }^{1}$
}

Additional index words. Hemiptera, Ortheziidae, insect pest resistance

Summary. The greenhouse orthezia (Orthezia insignis) is a serious and widespread pest of cultivated lantanas (Lantana sp.) in warmer regions of the world. Forty species and cultivars of lantanas were screened for their relative susceptibility to this insect pest. Results showed that two Florida native lantanas, pineland lantana $(L$. depressa) and buttonsage ( $L$. involucrata), were highly susceptible to infestation, with trailing lantana (L. montevidensis) and its cultivars and hybrids being somewhat less susceptible. Shrub lantana (L. camara) and its cultivars and hybrids were the least susceptible to greenhouse orthezia infestation, but some of these varieties are rather unattractive as landscape ornamentals and can become serious weeds.

$\mathrm{T}$ he greenhouse orthezia, a damaging insect pest, is native to Central America and South America (Booth et al., 1995) but is now pantropical in distribution. It is usually found in greenhouses in temperate parts of the world but in warmer locations such as Florida and southern California, it is commonly found infesting plants in the landscape.

The greenhouse orthezia is unusual in that long, posteriorly oriented white waxy filaments are secreted on females. These filaments typically ex-

University of Florida, Ft. Lauderdale Research and Education Center, 3205 College Avenue, Ft. Lauderdale, FL 33314

Florida Agriculture Experiment Station journal series R-07676. The cost of publishing this paper was defrayed in part by payment of page charges. Under postal regulations, this paper must therefore be marked advertisement solely to indicate this fact.

${ }^{1}$ Current address: USDA-ARS, 13601 Old Cutler Rd., Miami, FL 33158 tend twice the length of the body (Essig, 1926). The structure that the filaments form, called the ovisac, houses eggs produced by females. Nymphs hatching from the eggs crawl through a posterior opening on the ovisac onto the host plant. Like aphids, reproduction is parthenogenetic (Epila, 1986). The greenhouse orthezia is a sucking insect that feeds on plant sap. Honeydew secreted by the feeding insects supports the growth of sooty mold, which renders plants unsightly and reduces photosynthetic efficiency.

The host range of the greenhouse orthezia is extensive and it has been reported feeding on species within 34 families (Ben-Dov et al., 2000). It is considered to be a very damaging and even lethal pest of some lantanas. Management of the greenhouse orthezia is generally accomplished by application of botanical oils (Hussain et al., 1996) or by release and augmentation of ladybird beetle (Decadomiusbahamicus and Hyperaspis pantherina) predators (Bennett and Gordon, 1991, Booth et al., 1995). The purpose of this study was to determine if genetic resistance to the greenhouse orthezia exists among the numerous cultivars of lantanas grown as ornamentals in the United States.

\section{Materials and methods}

Rooted cuttings of 21 cultivars and/or species of lantana were potted into 2.8-L (0.75-gal) plastic containers using a 5 pine bark: 4 sedge peat : 1 sand substrate on 18 Apr. 1999. This substrate was amended with dolomitic limestone at $7.1 \mathrm{~kg} \cdot \mathrm{m}^{-3}\left(12 \mathrm{lb} / \mathrm{yard}^{3}\right)$ and Micromax (Scotts Co., Marysville, Ohio) at $890 \mathrm{~g} \cdot \mathrm{m}^{-3}\left(1.5 \mathrm{lb} /\right.$ yard $\left.^{3}\right)$. All pots received $22 \mathrm{~g}(0.7 \mathrm{oz})$ of Osmocote Plus 15N-3.9P-10K (Scotts Co., Marysville, Ohio) every 6 months. A second experiment containing 20 additional cultivars, plus $L$. involucrata as a repetition from the first experiment, was similarly set up on 2 Sept. 1999.

All plants were grown in a full sun nursery in Davie, Fla. (maximum photosynthetic photon flux = $\left.1900 \mu \mathrm{m} \cdot \mathrm{m}^{-2} \cdot \mathrm{s}^{-1}\right)$, where they received about $2 \mathrm{~cm}(0.8$ inch $)$ of water daily from overhead irrigation, plus natural rainfall. Ten replicate plants of each cultivar were arranged in a randomized complete-block design. Within 2 months of planting, all blocks of lantanas showed signs of infestation with 
Table 1. Percentage of lantana foliage infested with greenhouse orthezia. Data are means of 10 replicate plants.

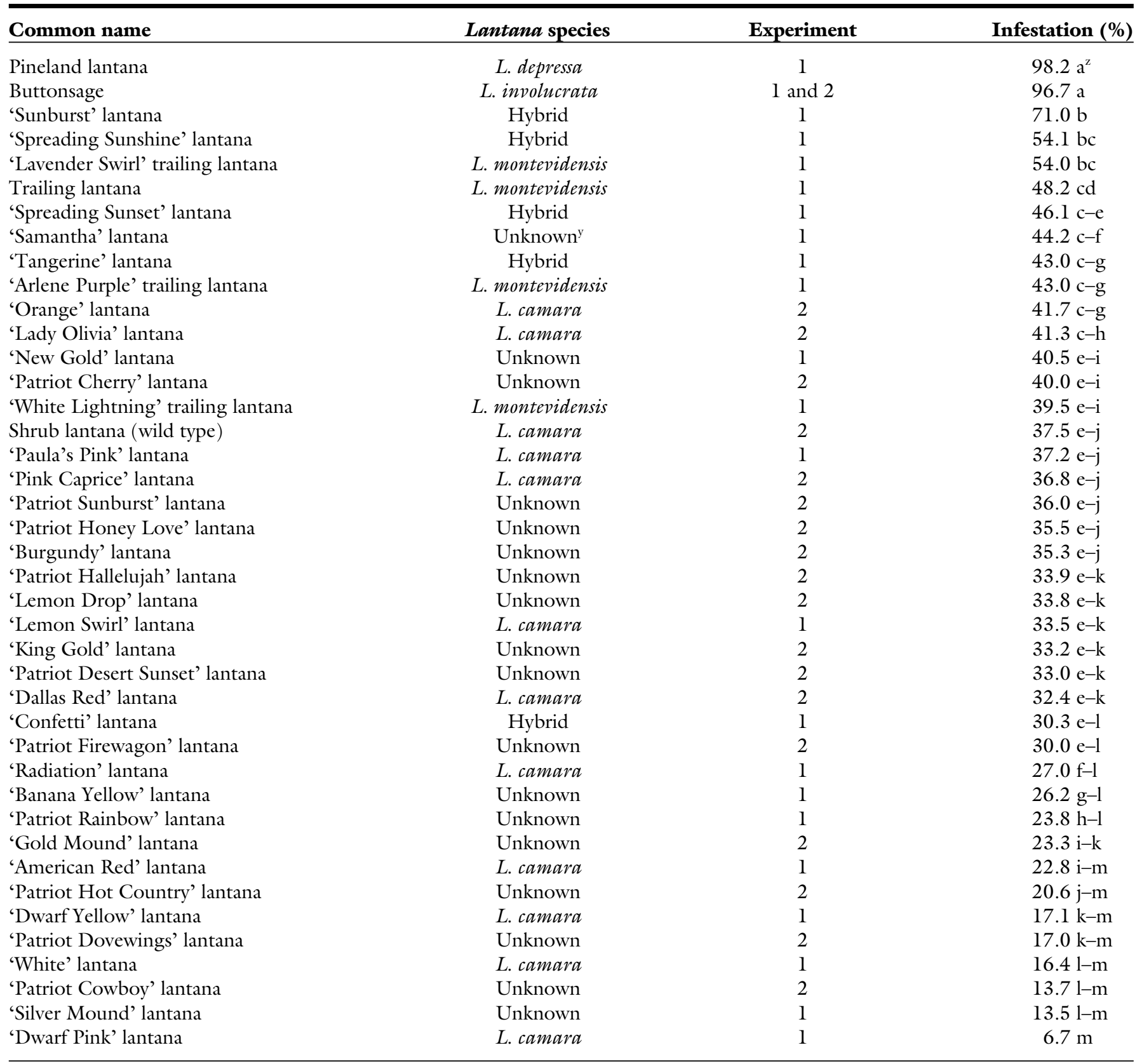

${ }^{\mathrm{z}}$ Mean separation by the Waller-Duncan $\mathrm{k}$ ratio method, $\mathrm{k}=100$.

yThe origin of cultivars listed without a species name is unknown. Most are probably selections of $L$. camara, but some may be interspecific hybrids.

greenhouse orthezia. Six months after planting, all plants were scored by both authors for the percentage of plant surface area covered with greenhouse orthezia and the percentage agreed upon by both authors for each plant was used in the analysis. Data were analyzed by analysis of variance (PROC GLM, SAS, SAS Systems, Cary, N.C.), with mean separation by the WallerDuncan k ratio method. Since mean infestation levels for L. involucrata used in both experiments were statistically (ANOVA) similar (96.2 and 97.3 for experiments 1 and 2, respectively) and overall means and SE for the two experiments were not significantly different $(39.9 \pm 1.9$ and $35.5 \pm 2.1$ for experiments 1 and 2 , respectively), the data from both experiments were combined and analyzed as a single data set.

\section{Results and discussion}

The mean percentage of foliage infested with greenhouse orthezia varied greatly among lantana cultivars from a low of $6.7 \%$ for 'Dwarf Pink' to more than $95 \%$ for $L$. depressa and $L$. involucrata (Table 1$)$. In general, $L$. camara cultivars and a few of its hybrids had the lowest infestation rates followed by L. montevidensis and the spreading hybrids that probably have L. montevidensis as one of their parents. The most highly susceptible lantanas were the two species native to southern Florida pinelands, L. depressa and L. involucrata.

Greenhouse orthezia has been considered for possible use as a biological control agent for L. camara, which is considered a noxious weed throughout much of the southeastern United States and Hawaii (Muniappan and Viraktamath, 1986; Perkins and Swezey, 1924). However, this study shows that $L$. camara and its improved cultivars appear to be much more resis- 
tant to greenhouse orthezia than the desirable Florida natives, L. depressa and L. involucrata. Unfortunately, many of the $L$. camara cultivars and similarlooking hybrids are not necessarily suitable for landscape use due to their leggy growth and/or seed production, making them aesthetically unattractive and potentially invasive. For example, the most resistant cultivar in this study, 'Dwarf Pink', is leggy and not particularly attractive in the landscape. However, L. camara-type cultivars such as 'Silver Mound', 'White', 'Patriot Dovewings' and 'Patriot Hot Country' are fairly resistant to greenhouse orthezia and are considered by the authors to be attractive and desirable landscape plants.

Due to its wide host range, the results obtained in this study were somewhat surprising considering the breadth of plant diversity upon which greenhouse orthezia feeds. The mechanism of resistance expressed by the various lantana cultivars to greenhouse orthezia is at this time unknown. In general, complex chemical and nutritive plant constituents (Bernays and Chapman, 1994) may be responsible for differences in host selection and colonization by greenhouse orthezia among the various cultivars. It is also possible that differences in physical attributes between lantana cultivars, such are tissue hardness, color, scent, and trichomes are responsible for observed differences.

In summary, in areas where greenhouse orthezia is a problem on cultivated lantanas, many of the $L$. camara cultivars and hybrids are fairly resistant to this pest. Lantana depressa and $L$. involucrata, and to a lesser extent, $L$. montevidensis and its hybrids, would be poor choices for use in areas where this pest is present. Care should be taken when selecting L. camara type cultivars to prevent the establishment of potentially invasive plants.

\section{Literature cited}

Ben-Dov, Y., D.R. Miller, and G.A.P. Gibson. 2001. ScaleNet. 23 Apr. 2001. <http://www.sel.barc.usda.gov/ scalenet/scalenet.htm $>$.

Bennett, F.D. and R.D. Gordon. 1991. New Florida ladybeetle (Coleoptera: Coccinellidae). Fla. Entomol. 74(4):598-599.

Bernays, E.A. and R.F. Chapman. 1994. Host-plant selection by phytophagous insects. Chapman and Hall, New York.

Booth, R.G., A.E. Cross, S.V. Fowler, and R.H. Shaw. 1995. The biology and taxonomy of Hyperaspispantherina ( $\mathrm{CO}^{-}$ leoptera: Coccinellidae) and the classical biological control of its prey, Orthezia insignis(Homoptera: Ortheziidae). Bull. Entomol. Res. 85:307-314.

Epila, J.S.O. 1986. Aspects of the biology of Orthezia insignis Browne (Ortheziidae: Homoptera) infesting Hamelia sphaerocarpa Ruiz \& Pav. (Rubiaceae) in Uganda-I. Life history. Insect Sci. Appl. 7:53-59.

Essig, E.O. 1926. Insects of western North America. Macmillan, New York.

Hussain, M.A., M. Puttaswamy, and C.A. Viraktamath. 1996. Effect of botanical oils on lantana bug, Orthezia insignis Browne infesting crossandra. Insect Environ. 2:85-86.

Muniappan, R. and C.A. Viraktamath. 1986. Status of biological control of the weed, Lantana camara in India. Trop. Pest Mgt. 32:40-42.

Perkins, R.C.L. and O.H. Swezey. 1924. The introduction into Hawaii of insects that attack lantana. Bul. Hawaiian Sugar Plantation Assn. Expt. Sta. 16.
Influence of

Nitrogen and Bagging on Fruit Quality and Mineral Concentrations
of 'BC-2 Fuji'
Apple

Additional INDEX wORds. fruit wrapping, high-density, Malus domestica, mineral nutrition, postharvest

Summary. The influence of three rates of nitrogen $(\mathrm{N})$ and fruit bagging on fruit peel and flesh mineral concentrations and fruit quality in 'BC-2 Fuji' apple (Malus domestica Borkh.) trees on Malling 9 (M.9) was studied. Increasing $\mathbf{N}$ application decreased fruit peel red color, fruit $\mathrm{N}$, iron $(\mathrm{Fe})$, and manganese (Mn). Fruit from trees receiving $10.72 \mathrm{oz}(303.9 \mathrm{~g}) \mathrm{N}$ per year had higher evolved ethylene and respiration during poststorage ripening tests. Bagging of fruit reduced fruit peel red color, soluble solids concentrations (SSC), and dry weight as compared to nonbagged fruit. Bagged fruit had higher $\mathbf{N}$, potassium $(\mathrm{K})$, and copper $(\mathrm{Cu})$ than nonbagged fruit. Fruit peel had a greater percentage of dry weight, and higher concentrations of all tested minerals compared to fruit flesh.

Authors wish to express their appreciation to the Idaho Apple Commission and Washington State Tree Fruit Research Commission for their financial support of this project. The cost of publishing this paper was defrayed in part by payment of page charges. Under postal regulations, this paper must therefore be marked advertisement solely to indicate this fact.

${ }^{1}$ Professor of pomology; corresponding author, Department of Plant, Soil, and Entomological Sciences, Parma Research and Extension Center, University of Idaho, 29603 U of I Lane, Parma, ID 83660.

${ }^{2}$ Associate professor of horticulture, University of Idaho. ${ }^{3}$ Professor of entomology, University of Idaho. ${ }^{4}$ Research associate of pomology, University of Idaho. ${ }^{5}$ Postdoctoral fellow, University of Idaho. 